\title{
EVALUASI RENCANA TINDAKAN DARURAT KEBAKARAN (RTDK) PADA BANGUNAN RUSUNAWA UNNES SEMARANG BERDASARKAN PETUNJUK TEKNIS DAN PERSEPSI MAHASISWA PENGHUNINYA
}

\author{
M. Husni Darmawan ${ }^{1}$, Bambang Setyohadi Kuswarna Putra ${ }^{2}$, Eko Budi Santoso ${ }^{3}$ \\ ${ }^{1,2,3)}$ Jurusan Teknik Sipil, Fakultas Teknik, Universitas Negeri Semarang (UNNES) \\ Kampus Unnes Gd E4, Sekaran, Gunungpati, Semarang 50229
}

\begin{abstract}
One important thing in supporting Reliability Building to meet safety, is building capabilities in tackling a fire hazard, set out the Fire Emergency Action Plan. Reliability Action Plan Emergency Fire is an important part of the safety aspects of a building, and it can beevaluated on the readiness of the hardware and software as well as a means of supporting the Action Plan Emergency Fire which managed the building. This research is motivated curiosity of how far the readiness of Fire Emergency Action Plan in Rusunawa UNNES and how the response, feedback or ratings by students as inhabitants of the performance systems fire prevention at this Rusunawa UNNES. Based on the results of 96 students, students' perceptions of readiness in Fire Emergency Action Plan are as follows. There are 6\% found APEF Rusunawa was in the excellent category; $72 \%$ found Rusunawa APEF UNNES Semarang was in good categories; $16 \%$ found Rusunawa APEF UNNES was in quite-good category and 6\% found Rusunawa UNNES APEFwas in not-good category.Suggestions needs for the manager enhance the safety aspects that form the Emergency Action PlanFire, by conducting periodic evaluation of the readiness of the system and the existing equipment.
\end{abstract}

Keywords :EPH, APEF In the Building, Student Perception

\begin{abstract}
Abstrak: Salah satu hal penting dalam menunjang Keandalan Bangunan Gedung untuk memenuhi aspek keselamatan, adalah kemampuan bangunan dalam menanggulangi bahaya kebakaran dengan tersusunnya Rencana Tindak Darurat Kebakaran. Keandalan Rencana Tindak Darurat Kebakaran merupakan bagian penting dari aspek keselamatan suatu bangunan gedung, dan ini dapat dievaluasi dari kesiapan perangkat keras (Hardware) dan perangkat lunak (Software) serta sarana pendukung Rencana Tindak Darurat Kebakaran (RTDK) yang di dikelola pada bangunan gedung tersebut.Penelitian ini dilatar belakangi keingintahuan seberapa jauh kesiapan Rencana Tindak Darurat Kebakaran (RTDK) Pada Rusunawa UNNES serta bagaimana respon, tanggapan atau penilaian oleh para mahasiswa sebagai penghuninya terhadap kinerja (performance) sistem penanggulangan bahaya kebakaran. Berdasarkan hasil penelitian dari 96 mahasiswa, diperoleh keterangan persepsi mahasiswa terhadap kesiapan Rencana Tindak Darurat Kebakaran adalah sebagai berikut : $6 \%$ berpendapat bahwa RTDK Rusunawa ini dalam kategori sangat baik; $72 \%$ berpendapat bahwa RTDK Rusunawa UNNES Semarang dalam kategori baik; $16 \%$ berpendapat bahwa RTDK Rusunawa UNNES ini dalam kategori Cukup baik dan 6\% berpendapat bahwa RTDK Rusunawa UNNES ini dalam kategori tidak baik.Saran perlunya pihak pengelola lebih meningkatkan aspek keselamatan yang berupa Rencana Tindak Darurat Kebakaran, dengan mengadakan evaluasi secara berkala terhadap kesiapan sistem maupun peralatan yang ada.
\end{abstract}

Kata kunci : EPH, RTDK Pada Bangunan Gedung, Persepsi mahasiswa

\section{PENDAHULUAN}

Kebutuhan tempat hunian bagi mahasiswa UNNES yang berasal dari luar kota, sangat dimengerti oleh pihak Universitas. Hal ini direspon oleh pihak Universitas Negeri Semarang (UNNES) dengan menyediakan fasilitas hunian massal yang berupa Rumah Susun Bertingkat atau yang disebut dengan
Rusunawa (Rumah Susun Sewa Sederhana Untuk Mahasiswa). Rusunawa ini merupakan salah satu fasilitas atau asrama yang dibangun oleh pihak Universitas Negeri Semarang (UNNES) untuk para mahasiswa baru yang kurang mampu dan lolos seleksi, khususnya penerima beasiswa Bidikmisi dan seluruh penghuninya adalah perempuan. 
Tujuanperencanaan dan perancangan dalam arsitektur adalah untuk menyediakan wadah bagi kegiatan manusia secara aman dan nyaman denganterpenuhinyaaspek keselamatan,aspekkesehatan,aspek kenyamanan dan aspek kemudahan baik bagi penghuninya maupun lingkungan sekitarnya.Akan tetapitidaksemuaperancangan arsitektur sesuai dengan tujuannya, sehingga mendorong adanya usaha untuk melakukan evaluasi terhadap hasil rancangan yang ada apakah keputusan yang diambil oleh perancang telah menghasilkan kinerja (performance) yang sesuai dengan kebutuhan para penghuninya.

Salah satu hal penting dalam menunjang Keandalan Bangunan Gedung untuk memenuhi aspek keselamatan, adalah kemampuan bangunan dalam menanggulangi bahayakebakaran dengan tersusunnya RencanaTindakDarurat Kebakaran. KeandalanRencanaTindakDarurat Kebakaran merupakan bagian penting dari aspek keselamatan suatu bangunan gedung, dan ini dapat dievaluasi dari kesiapan perangkat keras (Hard Ware) dan perangkat lunak (Soft Ware) serta sarana pendukung Rencana Tindak Darurat Kebakaran (RTDK) yang di dikelola pada bangunan gedung tersebut.

Penelitian ini dilatar belakangi keingintahuan seberapa jauh kesiapan Rencana Tindak Darurat Kebakaran (RTDK) Pada Rusunawa UNNES serta bagaimana respon, tanggapan atau penilaian oleh para mahasiswa sebagai penghuninya terhadap kinerja (performance) sistem penangulangan bahaya kebakaran di gedung Rusunawa UNNES Semarang ini. Karena sistem penanggulangan bahaya kebakaran merupakan salah satu aspek utama keselamatan gedung, yang meliputi: struktur bangunan gedung, kemampuan bangunan gedung dalam menangkal bahaya petir dan bahaya kelistrikan.

\section{LANDASAN TEORI Evaluasi Pasca Huni (EPH)}

Evaluasi adalah salah satu mekanisme pengawasan terhadap suatu kebijakan. Evaluasi biasanya ditujukan untuk menilai sejauh mana keefektifan kebijakan publik guna dipertanggungjawabkan kepada konstituennya. Evaluasi diperlukan untuk melihat kesenjangan antara "harapan" dan "kenyataan" (Dwidjowijoto, 2003:183).

$$
\text { Menurut Sudibyo (1989), Post }
$$
Occupancy Evaluation (POE) atau Evaluasi Pasca Huni merupakan kegiatan berupa peninjauan (pengkajian) kembali (evaluasi) terhadap bangunan-bangunan dan atau lingkunganbinaanyang telah dihuni. Menurut Danisworo (1989) manfaat dan keuntungan dilakukannya $P O E$ tergantung pada organisasi klien dan kerangka waktu, dapat dibagi atas manfaat dan keuntungan jangka pendek, jangka menengah dan jangka panjang. Keuntungan jangka pendek adalah keuntungan yang didapat dari pemanfaatan langsung temuan suatu proses $P O E$, yang meliputi :

a. Identifikasi dan solusi masalah dalam fasilitas yang bersangkutan.

b. Pengelolaan fasilitas yang tanggap terhadap nilai pemakai.

c. Peningkatan pemanfaatan ruang. 
d. Peningkatan sikap pemakai bangunan melalui partisipasinya dalam proses evaluasi.

e. Memberi pengertian akan implikasi perubahan yang dilandasi penghematan biaya terhadap performance.

f. Memberi masukan dan pengertian lebih baik akan konsekuensi suatu rancangan.

Penghuni bangunan atau pemilik bangunan mengharapkan bangunannya aman, nyaman dan berumur panjang. Harapan ini secara langsung akan menyangkut kondisi fisik bangunannya yang meliputi struktur, ventilasi, sanitasi dan pengaman bangunan serta sistem penyangganya (Sudibyo, 1989). Penyelamatan terhadap bahaya kebakaran; perhatian dalam melakukan evaluasi terutama dikaitkan dengan perancangan akan melibatkan perletakan (tangga darurat dan pemadam kebakaran) sirkulasi dan material bangunan, pemakaian alat pemadam terlalu sering atau sebaliknya karena tidak pernah dipakai dapat menimbulkan masalah jika suatu saat terjadi kebakaran.

\section{Petunjuk Teknis (J uknis) Rencana Tindak Darurat Kebakaran (RTDK) Pada Bangunan Gedung}

a) Pengertian

RencanaTindak Darurat Kebakaran (RTDK) Pada Bangunan Gedung yang diatur oleh Keputusan Direktur Jenderal Perumahan Dan Permukiman Departeman Permukiman Dan Prasarana Wilayah Nomor : 58 / KPTS/ DM/2002 Tentang Petunjuk Teknis Rencana Tindakan Darurat Kebakaran Pada Bangunan adalah strategi dari Manajemen Penanggulangan Kebakaran (MPK) untuk mengantisipasi bila terjadi keadaan darurat kebakaran atau lainnya dalam suatu bangunan gedung dan atau lingkungannya, dimana tiap bangunan gedung dan lingkungannya akan berbeda bentuk Rencana Tindak Darurat Kebakaran (RTDK) nya sesuai dengan situasi dan kondisi masing-masing.

\section{b) Tindakan}

Rencana Tindak Darurat Kebakaran (RTDK) Pada Bangunan Gedung ini terdiri dari berbagai tindakan, seperti tindakan untuk mengetahui / memperkirakan lokasi yang merupakan sumber api, memadamkan api, melokalisir penjalaran api, memberitahukan kepada penghuni/pengguna, upaya evakuasi, menghubungi Instansi Pemadam Kebakaran Kota, dan membantu operasional pemadaman oleh Petugas Pemadam Kebakaran.

\section{c) Perangkat Keras (Hardware)}

Adapun perangkat keras (hardware) Rencana Tindak Darurat Kebakaran (RTDK) Pada Bangunan Gedung terdiri dari :

1. Tim Penanggulangan Kebakaran (TPK)

2. Penghuni/Pengguna Bangunan

3. Sarana dan Prasarana Proteksi Kebakaran

4. Regu Dinas Pemadam Kebakaran

\section{d) Sarana Pendukung}

Berikut adalah sarana pendukung, yang terdiri dari :

1. Rencana Jalur Evakuasi

2. Rencana Tempat Berhimpun

3. P3K(Pertolongan Pertama PadaKecelakaan)

4. Akses Dinas Pemadam Kebakaran Kota 
e) Prosedur Tindak Darurat Kebakaran Pada Bangunan Gedung

JIKA TERLIHAT API ATAU ASAP

\section{UNTUK PETUGAS / DAN SATPAM}

1. Perkirakan / periksa sumber api atau asap, apakah korsleting listrik atau bukan

2. Bila akibat korsleting listrik jangan menggunakan air, tetapi segera putuskan semua aliran listrik

3. Usahakan memadamkan sumber api dengan tabung Pemadam Api Ringan (APAR)

4. Gunakan air bila dipastikan sumber air bukan berasal dari korsleting listrik

5. Segera bunyikan tanda bahaya kebakaran (alarm) jika api tidak segera dapat diatasi dan menelepon Dinas Kebakaran Kota

6. Mengumpulkan segera ketua/regu pelaksana keselamatan kebakaran (TPK)

7. Segera lakukan tindakan evakuasi bagi seluruh penghuni/pengguna

\section{UNTUK PENGHUNI / PENGGUNA GEDUNG}

1. Segera tinggalkan ruangan dalam dan capai jalan keluar (EXIT) tangga terdekat

2. Agar tetap tenang dan tidak panik

3. Berjalan dengan cepat, tapi jangan berlari

4. Utamakan keselamatan diri, bawa barang yang sangat penting saja dan tidak lebihbesar/berat dari tas tangan

5. Keluar kearah/ketempat yang telah ditentukan oleh REGU PENYIAPAN TEMPAT BERHIMPUN

6. Ikuti semua instruksi yang diberikan oleh REGU EVAKUASI, petugas keselamatan kebakaran atau petugas lainnya

7. Berjalandan berkumpul ditempat berhimpunyang telah ditentukan dan tunggu sampai ada berita aman atau pemberitahuan lebih lanjut.

\section{f) Kartu Pintar (Attention)}

Kartu Pintar adalah kartu berisi tulisan yang maksudnya mohon perhatian kepada para penghuni / pengguna ruangan bangunan gedung.Tulisan ini wajib diumumkan oleh Regu Informasi Internal (RII) melalui sistem informasi internal.Kartu ini dapat dibacakan oleh operator atau telah direkam terlebih dahulu.

1. Kartu Pintar "False Alarm", bila terjadi kebakaran kecil dan api sudah teratasi, atau alarm/bel berbunyi karena kesalahan teknis.

Kartu Pintar "FALSE ALARM"

1. Harap tenang dan tidak perlu panik, karena keadaan sudah teratasi

2. Kepada seluruh penghuni/pengguna diharap tenang, dan kembali tempat masing-masing

3. Terima-kasih

2. Kartu Pintar "Real Fire", bila terjadi kebakaran yang membahayakan.

Kartu Pintar "REAL FIRE"

1. Mohon perhatian, harap siaga dan tidak perlu panic

2. Telah terjadi kebakaran di ruang....

3. Seluruh penghuni/pengguna diharap segera di evakuasi

4. Ikuti petunjuk dari PETUGAS EVAKUASI

3. Kartu Pintar "Pasca Api"

Kartu Pintar "PASCA API"

1. Kepada seluruh penghuni

2. Kondisi api di ruangsaat ini telah dapat diatasi

3. Silahkan kembali ke ruang masing-masing dan kembali beraktifitas, kecuali ruangyang terbakar

4. Terima kasih 


\section{g) Diagram-Diagram Tindak Darurat Kebakaran Bangunan Gedung}

Guna memudahkan anggota satlaskar kebakaran bangunan gedung memahami fungsi dan tugas-tugasnya, maka perlu dibuat diagram alur dari RTDK yang akan dilakukan. Diagram ini dibuat sesuai dengan struktur organisasi Satlaskar yang ada dan harus sering dievaluasi dan disempurnakan ssuai dengan kondisi nyata yang dihadapi.

\section{Persepsi}

Persepsi merupakan suatu proses yang didahului dengan penginderaan, yaitu proses diterimanya stimulus oleh individu melalui alat indera. Alat indera ini merupakan alat penghubung antara individu dengan dunia luarnya (Branca, 1964). Sedangkan stimulus yang diindera ini kemudian oleh individu diorganisasikan dan diinterpretasikan, sehingga individu menyadari, mengerti tentang apa yang diindera itu, dan proses ini disebut persepsi.

Menurut Moskowitz dan Orgel (1969), persepsi merupakan proses yang integrated dalam diri individu terhadap stimulus yang diterimanya. Dengan demeikian dapat dikemukakan bahwa persepsi itu merupakan pengorganisasian,

penginterpretasian terhadap stimulus yang diintegrated dalam diri individu. Dengan persepsi, individu akan mempelajari tentang keadaan disekitarnya dan juga keadaa diri sendiri (Davidoff,1981). Karena itulah banyak penelitian mengenai persepsi yang berkaitan dengan alat/indera penglihatan (mata). Persepsi adalah proses dimana seseorang memperoleh informasi dari lingkungan sekitar. Persepsi merupakan suatu hal yang aktif. Persepsi memerlukan pertemuan nyata dengan suatu benda yang juga membutuhkan proses kognisi sera afeksi. Persepsi membantu individu untuk menggambarkan dan menjelaskan apa yang dilakukan oleh individu. Persepsi seseorang dapat menjelaskan teori tentang desain arsitektur yang mendasarinya.

\section{Rusunawa UNNES Semarang}

Rusunawa UNNES adalah Rumah Susun Sewa Sederhana Untuk Mahasiswa Universitas Negeri Semarang yang diperuntukkan bagi Maba (mahasiswa baru), khususnya penerima beasiswa Bidikmisi dimana seluruh penghuninya adalah perempuan. Rusunawa UNNES Semarang dibangun di Kelurahan Kalisegoro Kecamatan Gununpati Kota Semarang.

Menurut UU No.20 Tahun 2011 Tentang Rumah Susun, ada beberapa hal yang terkait dengan Rusun yang meliputi pengertian rumah susun, pembinaan rumah susun, pembangunan rumah susun, persyaratan teknis rumah susun, prasarana, sarana dan utilitas umum lingkungan rumah susun, pemanfaatan rumah susun, pengelolaan rumah susun dan komponen pembangunan rumah susun.

Adapun pengertian Rumah Susun menurut UU No 20 Tahun 2011 Tentang Rumah Susun adalah bangunan gedung bertingkat yang dibangun dalam suatu lingkungan yang terbagi dalam bagian-bagian yang distrukturkan secara fungsional, baik dalam arah horizontal maupun verikal dan merupakan satuan-satuan yang masingmasing dapat memiliki dan digunakan secara terpisah, terutama untuk tempat hunian yang dilengkapi dengan bagian bersama, benda 
bersama dan tanah bersama. Persyaratan teknis pembangunan rumah susun ini, terdiri atas :

1. Tata bangunan yang meliputi persyaratan peruntukan lokasi serta intensitas dan arsitektur bangunan

2. Keandalan bangunan yang meliputi persyaratan keselamatan, kesehatan, kenyamanan dan kemudahan.

3. Prasarana, sarana dan utilitas umum lingkungan harus mempertimbangkan :

- Kemudahan dan keserasian hubungan dalam kegiatan sehari-hari

- Pengamanan jika terjadi hal-hal yang membahayakan seperti bahaya kebakaran

4. Ketentuan lebih lanjut mengenai standar pelayanan minimal prasarana, sarana dan utilitas umum diatur dengan Peraturan Menteri.

\section{METODOLOGI}

Sistem pengelolaan pencegahan bahaya kebakaran pada bangunan gedung Rusunawa UNNES Semarang yang meliputi peralatan pencegahan dan pemadam kebakaran dan sistem evakuasi penghuni. Populasi dalam penelitian ini adalah seluruh mahasiswa yang menjadi penghuni Rusunawa UNNES yang bejumlah sekitar 306 mahasiswa (Data Penghuni Rusunawa UNNES Tahun 2011).

Penentuan sampel untuk penelitian ini dilakukan dengan cara acak sederhana (simple random sampling), dimana semua penghuni dalam satu kamar Rusunawa UNNES ini mempunyai kesempatan yang sama untuk dipilih sebagai sampel. Proses evaluasi keandalan bangunan ini merupakan sebuah penilaian dari kinerja gedung berdasarkan apa yang dirasa dan dialami oleh penghuni Rusunawa UNNES Semarang.

Evaluasi terhadap Rencana Tindak Darurat Kebakaran Pada Bangunan Rusunawa UNNES yang dilakukan oleh peneliti merupakan salah satu bagian dari evaluasi keandalan bangunan secara keseluruhan. Selain berdasarkan persepsi penghuninya juga berdasarkan petunjuk teknis yang ada. Untuk menentukan jumlah sampel digunakan rumus Slovin sebagai berikut :

$\mathrm{n}=\frac{\mathrm{N}}{1+\mathrm{N} \cdot \mathrm{e}^{2}}$

$\mathrm{n}=$ jumlah sampel

$\mathrm{N}=$ jumlah populasi

$\mathrm{e}=$ persentase kelonggaran ketidak telitan

Perhitungan jumlah sampel mahasiswa penghuni Rusunawa UNNES Semarang, adalah sebagai berikut :

$n=\frac{306}{1+306 \cdot(0,1)^{2}}$
$n=\frac{306}{4,06}$
$n=75,37$

Berdasarkan perhitungan diatas, maka jumlah sampel dalam penelitian ini adalah sebanyak 75,73 orang dan dibulatkan menjadi sebanyak 76 orang.

Pengambilan sampel dilakukan dengan cara sampel acak sederhana (simple random sampling). Bangunan Rusunawa ini terdiri dari 96 kamar untuk 306 mahasiswa, jadi dalam satu kamar rata-rata dihuni oleh 4 orang mahasiswa. Untuk mempermudah pengambilan sampling, peneliti memberikan satu kuesioner untuk satu mahasiswa dalam 
satu kamar, ini berarti bahwa semua penghuni kamar mempunyai kesempatan yang sama untuk terpilih sebagai sampel. Agar setiap kamar terwakili sebagai sampel, jumlah sampel disesuaikan dengan jumlah kamar yang ada, yaitu 96 sampel.

Terdapat dua variabel yang menjadi obyek penelitian, yaitu variabel bebas dan variabel terikat .

1. Variabel bebasnya adalah persepsi mahasiswa sebagai penghuni Rusunawa UNNES Semarang.

2. Variabel terikatnya, yaitu Rencana Tindak Darurat Kebakaran Bangunan Rusunawa Unnes Semarang.

Pengumpulan data dilakukan dengan cara teknik wawancara, kuesioner, observasi dan dokumentasi. Wawancara dilakukan secara langsung dengan nara sumber Rusunawa UNNES untuk memperoleh datadata tentang kondisi dari sistem pengelolaan pencegahan dan pemadam kebakaran. Kuesioner dilakukan dengan cara menyebar angket yang berisikan pernyataan-pernyataan yang berkaitan dengan Rencana Tidak Darurat Kebakaran Bangunan Rusunawa UNNES kepada responden guna mengetahui respon tentang kesiapan Rencana Tindak Darurat (RDTK) Pada Rusunawa UNNES.

Teknik observasi dilakukan pengamatan langsung terhadap kondisi peralatan dan kesiapan Rencana Tindak Darurat Kebakaran (RTDK) Pada Rusunawa UNNES dan memvisualkannya melalui rekaman foto.

Data yang diperoleh diolah dan ditabulasikan dan dianalis menggunakan metode deskriptif prosentase. Karena data angket berupa data kualitatif, untuk dapat dianalisis maka harus dirubah menjadi data kuantitatif. Untuk menentukan skor digunakan skala Likert, diamana skala merupakan ukuran gabungan yang didasarkan pada struktur intensitas pertanyaan-pertanyaan. Cara pengukuran adalah dengan menghadapkan seseorang responden dengan sebuah pertanyaan dan kemudian diminta untuk memberikan jawaban.

Tabel 1. Skoring Jawaban

\begin{tabular}{ccc}
\hline No & JAWABAN & SKOR \\
\hline 1 & Sangat Setuju & 5 \\
\hline 2 & Setuju & 4 \\
\hline 3 & Ragu-ragu & 3 \\
\hline 5 & Tidak Setuju & 2 \\
\hline
\end{tabular}

Setelah seluruh nilai direkap, dihitung prosentasenya dengan menggunakan rumus sebagai berikut :

Dimana :

$$
D \rho=\frac{n}{N} \times 100 \%
$$

$$
\begin{aligned}
& D \rho=\text { Prosentase dari nilai yang } \\
& n=\text { Jumlah nilai yang diperoleh } \\
& N=\text { Jumlah seluruh nilai (Skor }
\end{aligned}
$$

Hasil yang diperoleh dikonsultasikan dengan tabel kategorisasi. Untuk menentukan kategori Deskriptif Prosentase (DP) yang diperoleh, maka dibuat tabel kategorisasi yang disusun dalam perhitungan sebagai berikut: 
1. Prosentase maksimak

$$
:(5 / 5) \times 100 \%=100 \%
$$

2. Prosentase minimal

$$
:(1 / 5) \times 100 \%=20 \%
$$

3. Rentang prosentase

$$
: 100 \%-20 \%=80 \%
$$

4. Interval kelas prosentase

$$
: 80 \% / 5=16 \%
$$

Tabel 2. Kategorisasi Variabel Penelitian

\begin{tabular}{c|c|c}
\hline No & $\begin{array}{c}\text { INTERVAL } \\
\text { PROSENTASE }\end{array}$ & KRITERIA \\
\hline 1 & $84 \%<$ Skor $\leq 100 \%$ & Sangat Baik \\
\hline 2 & $68 \%<$ Skor $\leq 84 \%$ & Baik \\
\hline 3 & $52 \%<$ Skor $\leq 68 \%$ & Cukup Baik \\
\hline 4 & $36 \%<$ Skor $\leq 52 \%$ & Tidak Baik \\
\hline 5 & $20 \%<$ Skor $\leq 36 \%$ & $\begin{array}{c}\text { Sangat Tidak } \\
\text { Baik }\end{array}$ \\
\hline
\end{tabular}

Sumber : Data Penelitian, 2015

\section{HASIL PEMBAHASAN}

\section{Rencana Tindak Darurat Kebakaran (RTDK) Pada Rusunawa UNNES Semarang}

Menurut Peraturan Menteri Pekerjaan Umum No. 05/PRT/M/2007 Tentang Pedoman Teknis Pembangunan Rumah Susun Sederhana, bangunan Rusun Bertingkat Tinggi harus dilengkapi dengan sistem Proteksi Pasif dan sistem Proteksi Aktif. Yang dimaksud dengan sistem Proteksi Pasif disini adalah konstruksi di Rusun dapat memperlambat api apabila terjadi kebakaran didasarkan pada fungsi / klasifikasi resiko kebakaran, geometri ruang, bahan bangunan terpasang, dan jumlah ataupun kondisi penghuni dalam bangunan gedung.

Sedangkan yang dimaksud dengan sistem Proteksi Aktif adalah sebuah sistem atau peralatan yang dapat dijadikan Proteksi saat terjadi kebakaran. Pada sistem Proteksi Aktif yang perlu diperhatikan meliputi : sistem pemadam kebakaran, baik berupa APAR, Sprinkler, hydrant box maupun hidran pilar, sistem deteksi api/asap, fire alarm, sistem pengandalian asap dan pusat pengendali kebakaran.

Untuk perangkat keras (hardware) pada Rencana Tindak Darurat Kebakaran pada Rusunawa UNNES belum terbentuk adanya Tim Penanggulangan Kebakaran (TPK), sedangkan Sarana dan Prasarana Proteksi Kebakaran yang ada berupa Hydrant Box (luar dan dalam bangunan), APAR yang terletak di setiap koridor lantainya, Fire Alarm dan Alat Deteksi Kebakaran pada tiap kamarnya. Untuk alat proteksi kebakaran di luar bangunan adalah Hidran Pilar yang berada disetiap sudut bangunan.

Untuk perangkat lunak (software) yang terdiri dari Struktur Organisasi TPK, Prosedur Tindakan Darurat, Kartu Pintar (Attention) dan Diagram Tindakan Darurat Kebakaran belum terbentuk secara formal, sedangkan Sarana Pendukung seperti Jalur Evakuasi, Rencana Tempat Berhimpun, P3K dan Akses Regu Dinas Pemadam Kebakaran Kota sudah tersedia.

\section{Persepsi Mahasiswa Terhadap Rencana Tindak Darurat Kebakaran Pada Rusunawa UNNE S Semarang}

Dari analisis data jawaban mahasiswa terhadap pernyataan tentang Rencana Tindak Darurat Kebakaran (RTDK) Pada Rusunawa UNNES, didapat angka prosentase seperti pada Tabel 3. 
Tabel 3. Distribusi aspek keselamatanbangunan pada indikatorkemampuan terhadap bahaya kebakaran

\begin{tabular}{ccccc}
\hline Interval Prosentase & Kriteria & Frekuensi & Prosentase & $\begin{array}{c}\text { Rata-rata } \\
\text { klasikal }\end{array}$ \\
\hline $84 \%<$ Skor $\leq 100 \%$ & Sangat Baik & 6 & $6 \%$ & $72,1 \%$ \\
\hline $68 \%<$ Skor $\leq 84 \%$ & Baik & 69 & $72 \%$ & $16 \%$ \\
\hline $52 \%<$ Skor $\leq 68 \%$ & Cukup & 15 & $6 \%$ \\
\hline $36 \%<$ Skor $\leq 52 \%$ & Tidak Baik & 6 & $0 \%$ & Baik \\
\hline & Sangat Tidak Baik & 0 & $100 \%$ & \\
\hline
\end{tabular}

Sumber: Data Penelitian, 2012

Berdasarkan tabel tersebut diatas dapat diketahui bahwa dari 96 mahasiswa diperoleh respon persepsi mahasiswa tentang kemampuan bangunan Rusunawa UNNES terhadap bahaya kebakaran sebagai berikut bahwa 6 mahasiswa (6\%) berpendapat bahwa keandalan bangunan Rusunawa UNNES ditinjau dari indikator kemampuan bangunan terhadap bahaya kebakaran termasuk dalam kategori Sangat Baik, 69 mahasiswa (72\%) berpendapat bahwa keandalan bangunan Rusunawa UNNES ditinjau dari indikator kemampuan bangunan terhadap bahaya kebakaran termasuk dalam kategori Baik, 15 mahasiswa (16\%) berpendapat bahwa keandalan bangunan Rusunawa UNNES ditinjau dari indikator kemampuan bangunan terhadap baha kebakaran termasuk dalam kategori Cukup Baik, 6 mahasiswa (6\%) berpendapat bahwa keandalan bangunan Rusunawa UNNES ditinjau dari indikator kemampuan bangunan terhadap bahaya kebakaran termasuk dalam kategori Tidak baikdan tidak ada (0\%) mahasiswa yang berpendapat bahwa bangunan RusunawaUNNES ditinjau dari indikator kemampuan bangunan terhadap bahaya kebakaran termasuk dalam kategori sangat tidak baik.
Rusunawa Unnes ini sudah memiliki sistem proteksi aktif yang berupa peralatan yang dapat dijadikan proteksi pada saat terjadi kebakaran. Disetiap koridor dalam Rusunawa ini terdapat Hydrant Box dan APAR (Alat Pemadam Api Ringan) yang diletakkan ditengah Koridor disetiap lantainya. Di depan halaman juga terdapat Hydrant Box dan Hidran Pilar. Disetiap ruangan Rusunawa ini juga dilengkapi dengan sistem deteksi kebakaran, sedangkan untuk alarm kebakaran terletak dipintu masuk Rusunawa. Sistem proteksi aktif ini juga dilengkapi dengan sistem pengendali asap kebakaran, dan pusat pengendalian kebakaran.

Berdasarkan fakta dilapangan, material bangunan dari Rusunawa ini merupahan bahan-bahan yang dapat membatasi kecepatan menjalarnya api bila terjadi kebakaran, karena sedikit bahan bangunan yang terbuat dari bahan kayu. Kisi-kisi jendeladan pintu luar terbuat dari bahan stainless, konstruksi dindingnya menggunakan bahan precast serta banyaknya lubang-lubang penghawaan sehingga dapat membatasi kecepatan menjalarnya api. Sistem Pendeteksian api atau asap berikut sistem pemadam kebakarannya menempel pada plafon disetiap ruang dalam Rusunawa 
UNNES ini, selain itu juga di lantai satu terdapat alarm kebakaran (fire alarm) yang ditempatkan di pos jaga Satpam dan dapat berbunyi secara otomatis apabila terjadi kebakaran didalam Rusunawa ini.Untuk pemadaman kebakaran didalam gedung digunakan Hydrant Box, sedangkan untuk pemadaman dari luar gedung menggunakan Hidran Pilar.Untuk Hydrant Box diletakkan ditengah koridor pada setiap lantai, sedangkan untuk hidran pilar terletak pada setiap sudut halaman gedung. Semua hidran ini terhubungkan dengan tangki air diatap (roof tank)dan tangki yang ada dibawah (ground tank), sebagai sumber airnya.

\section{KESIMPULAN}

1. Hasil analisis deskripsi tentang Rencana Tindak Darurat Kebakaran Pada Bangunan Rusunawa UNNES Semarang, belum sepenuhnya memenuhi persyaratan pada Petunjuk Teknis Rencana Tindakan Darurat Kebakaran Pada Bangunan Nomor : 58/KPTS/DM/2002. Akan tetapi secara keseluruhan telah memenuhi persyaratan untuk penghuniannya.

2. Berdasarkan hasil penelitian dapat diketahui dari 96 mahasiswa diperoleh respon persepsi tentang keandalan bangunan Rusunawa UNNES ditinjau dari indikator kemampuan bangunan terhadap bahaya kebakaran, sebagai berikut :

- $6 \%$ berpendapat bahwa keandalan bangunan dalam kategori Sangat Baik,

- $72 \%$ berpendapat bahwa keandalan bangunan dalam kategori Baik,

- $16 \%$ berpendapat bahwa keandalan bangunan dalam kategori Cukup Baik,
- $6 \%$ berpendapat bahwa keandalan bangunan dalam kategori Tidak baik

\section{DAFTAR PUSTAKA}

Ali, Mohammad. 1993. Strategi Penelitian Pendidikan. Bandung : Angkasa.

Arikunto, Suharsini.2006. Prosedur Penelitian Suatu Pendekatan Praktik (Edisi Revisi VI).Jakarta : PT Rineka Cipta.

Badan Standardisasi Nasional. 2000. "SNI 036390-2000 :Konservasi Energi Sistem Tata Udara Pada Bangunan Gedung.Jakarta : Author

Badan Standardisasi Nasional. 2001. "SNI 032396-2001. Tata Cara Perancangan Sistem Pencahayaan Alami Pada Bangunan Gedung.Jakarta : Author

Ching, Francis DK. 2000. Arsitektur : Bentuk, Ruang dan Tatananya.Jakarta : Erlangga.

Kementrian Pekerjaan Umum. Peraturan Menteri Pekerjaan UMUM Nomor : 05/PRT/M/2007 Tentang Pedoman teknis Pembangunan Rumag Susun Sederhana Bertingkat Tinggi.

Keputusan Direktur Jenderal Perumahan Dan Permukiman Departemen Permukiman Dan Prasarana Wilayah Nomor : 58 / KPTS / DM / 2002 Tentang Petunjuk Teknis Rencana Tindakan Darurat Kebakaran Pada Bangunan

Apriyanto, T., 2008. Kerangka Evaluasi Pengembangan Terminal Bus Antar Kota. Jurnal Teknik Sipil \& Perencanaan. Hal: 85-92. Semarang: Teknik Sipil FT Unnes. 